\title{
EXCESS WEIGHT AND HIGH BLOOD PRESSURE IN SCHOOLCHILDREN: PREVALENCE AND ASSOCIATED FACTORS
}

\author{
Luciana Tornquist ${ }^{1}$, Debora Tornquist ${ }^{2}$, Cézane Priscila Reuter ${ }^{3}$, Leandro Tibiriçá Burgos ${ }^{4}$, \\ Miria Suzana Burgos ${ }^{5}$
}

DOI: http://dx.doi.org/10.7322/jhgd.103018

\begin{abstract}
Introduction: Recent studies have indicated that increases in overweight and obesity rates as well as cardiovascular risk factors, such as hypertension, are occurring at younger ages. However, the causes and factors associated with these increases are still difficult to determine. Objective: To identify the associated factors and the prevalence of overweight and high blood pressure among schoolchildren. Methods : One thousand eight hundred sixty-eight students comprised the sample. The data were obtained through anthropometric measurements, blood pressure measurements, cardiopulmonary evaluations and questionnaires. Descriptive statistics, chi-square tests and Poisson regressions ( $p \leq 0.05$ ) were used. Results: In this sample, $28.6 \%$ and $15.9 \%$ of the students were overweight and had high blood pressure, respectively. The males were found to be more susceptible to both of the studied risk factors. The prevalence of high blood pressure among the adolescents was 1.173 - fold greater than that among the children. In contrast, adolescence itself was a protective factor in terms of overweight $(\mathrm{RP}=0754)$. The prevalence of overweight in the children with increased waist circumferences and poor cardiopulmonary aptitudes were increased by 5.5 - and 1.3 - fold, respectively. Conclusion: The prevalence of overweight and high blood pressure in the school population was high in the investigated city. Cardiorespiratory aptitude, increased waist circumference and family history exhibited influences on overweight and high blood pressure.
\end{abstract}

Key words: overweight, obesity, arterial pressure, risk factors, child, adolescent.

\section{INTRODUCTION}

Obesity and hypertension are growing health problems among the Brazilian and mundial populations $\mathbf{s}^{1,2}$. Despite the large number of studies of obesity, its causes remain difficult to determine because it is a multifactorial disease that is related to environmental factors, including lifestyle, and physiological factors, such as genetics ${ }^{3,4}$.

Similarly, cardiovascular diseases are also associated with genetic factors and lifestyle, and there is evidence that the severity of atherosclerosis is directly proportional to the number of risk factors to which each subject is exposed that that these effects become more evident with advancing age ${ }^{2,5}$.

However, current studies have warned of the increasing prevalence of obesity and hypertension among children and adolescents ${ }^{2,6}$. This is a troubling situation because the presences of these conditions in childhood and adolescence are strong predictors of their occurrence in adulthood 6,7 .
Nevertheless, these conditions are modifiable risk factors and therefore should be the focus of preventive and educational actions particularly with regard to the adoption of healthy lifestyle habits because the habits acquired in childhood tend to persist into adulthood ${ }^{3,5,7}$.

We emphasize the importance of conducting investigations related to obesity and high blood pressure to characterize the affected populations and direct programmes and strategies that enable the diagnosis and treatment of these populations. The objective of this study was to identify the prevalence of overweight and high blood pressure and the associated factors among schoolchildren from southern Brazil.

\section{METHODS}

A cross-sectional study was conducted with a sample of schoolchildren of both sexes between

1 Master's Student in Health Promotion. University of Santa Cruz do Sul - UNISC; Physical Education Professor.

2 Master's Student in Health Promotion. University of Santa Cruz do Sul - UNISC; Physical Education Professor.

3 Doctoral Student in Child and Adolescent Health. Federal University of Rio Grande do Sul - UFRGS. Pharmaceutical. Professor of Physical Education and Health Department. University of Santa Cruz do Sul - UNISC.

4 Master. Professor of Physical Education and Health Department. University of Santa Cruz do Sul - UNISC.

5 Doctor. Professor of Post-graduate Program in Health Promotion and Physical Education and Health Department. University of Santa Cruz do Sul - UNISC.

Corresponding author: Miria Suzana Burgos. E-mail: mburgos@unisc.br

Suggested citation: Tornquist L, Tornquist D, Reuter CP, Burgos LT, Burgos MS. Excess weight and high blood pressure in schoolchildren: prevalence and associated factors. Journal of Human Growth and Development. 25(2): 216-223. DOI: http://dx.doi.org/10.7322/ jhgd.103018

Manuscript submitted: oct 22 2014. Accepted for publication: apr 252015. 
the ages of seven and seventeen who were enrolled in schools in the municipality of Santa Cruz do Sul, Rio Grande do Sul. The study included nineteen schools, fourteen of which were located in urban areas, and five were in rural zones. The schools were randomly selected based on stratified cluster sampling. Among the evaluated schools, ten offered only elementary education, and nine included primary and secondary education. In all of the evaluated schools, at least one class in each year and stage of education was invited to participate.

The data collection was conducted in 2011 and 2012. The survey was approved by the Research Ethics Committee with Human Beings of the University of Santa Cruz do Sul (process 2525/10), and all parents or guardians provided written consent authorizing the participation of the schoolchildren in the study. The authors declare that they have no conflicts of interest related to this study. One thousand nine hundred sixty-three schoolchildren joined the study and performed the evaluations. Due to data inconsistencies or the submission of incomplete data, 96 subjects were excluded from the study. Thus, the final number of included subjects was 1867.

Subjects up to twelve years of age were considered children, and those older than twelve were considered adolescents according to the criteria of the Child and Adolescent Statute ${ }^{8}$. Socioeconomic status was classified according to the Associação Brasileira de Empresas de Pesquisa - ABEP criteria ${ }^{9}$; thus, the subjects were separated into eight distinct economic classes ( $A 1, A 2, B 1$, $B 2, C 1, C 2, D$ and E). However, for this study, these classes were reduced to the following three groups: higher economic class (A1, A2, B1 and B2), intermediate class ( $\mathrm{C} 1$ and $\mathrm{C} 2$ ) and lower class (D and $\mathrm{E}$ ).

We conducted anthropometric measurements of weight and height (direct measurements) and subsequently calculated the body mass indices (BMI = weight/height). The BMIs were classified using the percentile $(p)$ curves of the $\mathrm{CDC} / \mathrm{NCHS}^{10}$ according to gender and age; thus, the schoolchildren were classified as low weight ( $<\mathrm{p} 5)$, normal weight ( $\leq \mathrm{p} 5$ and $<\mathrm{p} \mathrm{85}$ ), overweight ( $p \geq 85$ and $<p 95$ ) and obese ( $\geq 95)$. In the present study, the term "excess weight" (SE) refers to the overweight and obese students, i.e., those with BMIs above the 85th percentile. Waist circumferences (WCs) were measured with an inelastic tape measure with $1-\mathrm{mm}$ resolution at the narrowest part of the trunk between the ribs and the iliac crest and were subsequently classified according to criteria established by Taylor et $a^{11}$.

A single evaluator performed all of the blood pressure measurements with the student sitting at rest. Sphygmomanometers were used at the brachial perimeter of the left arm in conjunction with a stethoscope. Due to the wide range of ages assessed, we used clamps with three different cuff sizes, i.e., paediatric, adolescent and adult. The clamp size was selected according to the age and a measurement of the circumference of the student's arm. The classifications were performed according to the percentiles for age, sex and height and were considered normal at $<$ the $90^{\text {th }}$ percentile, borderline between the $90^{\text {th }}$ and $95^{\text {th }}$ percentiles and hypertensive (stages 1 and 2 ) above the $95^{\text {th }}$ percentile in accordance with the VI Brazilian Hypertension Guidelines ${ }^{12}$. In the present study, "high blood pressure" (HBP) was defined by a systolic (SBP) or diastolic blood pressure (DBP) above the $90^{\text {th }}$ percentile, i.e., the borderline and hypertensive students included in this category.

Cardiorespiratory fitness was assessed using the 9-minute test from the PROESP-BR ${ }^{13}$ manual. The histories of hypertension and obesity were selfreported by the parents of the schoolchildren with reference to the existence of obesity, hypertension or both in the fathers and mothers of the schoolchildren.

The data were analysed with SPSS 20.0 (IBM, Armonk, NY, USA) for Windows using descriptive analyses (frequencies and percentages). The analyses of the associations between variables were performed using the chi-square method at a $p \leq 0.05$ significance level. To evaluate the prevalence ratios for overweight and high blood pressure, we used Poisson regressions ( $p \leq 0.05)$.

\section{RESULTS}

The characteristics of the subjects are shown in Table 1. One thousand eight hundred sixty-seven schoolchildren were evaluated, and there were greater percentages of females (54.4\%) and adolescents $(51.5 \%)$. Regarding the other factors studied, the prevalence of a low level of cardiorespiratory fitness was $37.4 \%, 19.1 \%$ of the students had high waist circumferences, and the prevalences of obesity and hypertension among the father, mother, or both were $10.7 \%$ and $27.6 \%$, respectively (Table 2 ).

Table 1: Characteristics of the evaluated schoolchildren; n (\%)

\begin{tabular}{lr} 
Gender & \\
Male & $851(45.6)$ \\
Female & $1016(54.4)$ \\
Age group & \\
$\quad$ Children & \\
Adolescent & $905(48.5)$ \\
School type & $962(51.5)$ \\
$\quad$ Private & \\
Public & $100(5.4)$ \\
Residence region & $1767(94.6)$ \\
Centre & \\
Periphery & \\
Rural & $365(19.5)$ \\
Socioeconomic class & $795(42.6)$ \\
A and B & $707(37.9)$ \\
C & \\
D and E & $910(48.7)$ \\
TOTAL & $884(47.3)$ \\
\hline
\end{tabular}


Table 2: Prevalence of the studied variables; $\mathrm{n}(\%)$

$\begin{array}{lr}\text { CRF }^{*} & \\ \text { High levels } & 1168(62.6) \\ \text { Low levels } & 699(37.4) \\ \text { WC* } & \\ \quad \text { Normal } & 1511(80.9) \\ \text { Elevated } & 356(19.1) \\ \text { Obesity in Father/Mother } & \\ \text { No } & 1668(89.3) \\ \text { Yes } & 199(10.7) \\ \text { Hypertension in Father/Mother } & \\ \text { No } & 1352(72.4) \\ \text { Yes } & 515(27.6) \\ \text { TOTAL } & 1867(100) \\ \text { *CRF = cardiorespiratory fitness ; } & \text { WC = waist }\end{array}$

The prevalence of excess weight was $28.6 \%$ ( $16.1 \%$ overweight and $12.5 \%$ obese), and excess weight was significantly more common among the males, the children, between the periphery, those with low levels of cardiorespiratory fitness, those with increased waist circumferences and those with fathers and/or mothers who were obese (Table 3 ). The students with increased waist circumferences and low levels of cardiorespiratory fitness exhibited excess weight prevalence that was elevated by 5.5$(p<0.001)$ and 1.3 -fold $(p=0.013)$, respectively. The adolescents were less likely to have excess weight than the children $(P R=0.754)$.

Among all students, $15.9 \%$ were identified as having high blood pressure $(7.3 \%$ borderline and $8.6 \%$ hypertensive). The prevalence of this condition was significantly higher the in males, the adolescents, the students with high WCs and the students with fathers and/or mothers with hypertension. Additionally, high blood pressure was

Table 3: Prevalence of overweight and obesity according to the studied variables and prevalence ratios for excess weight (overweight and obesity)

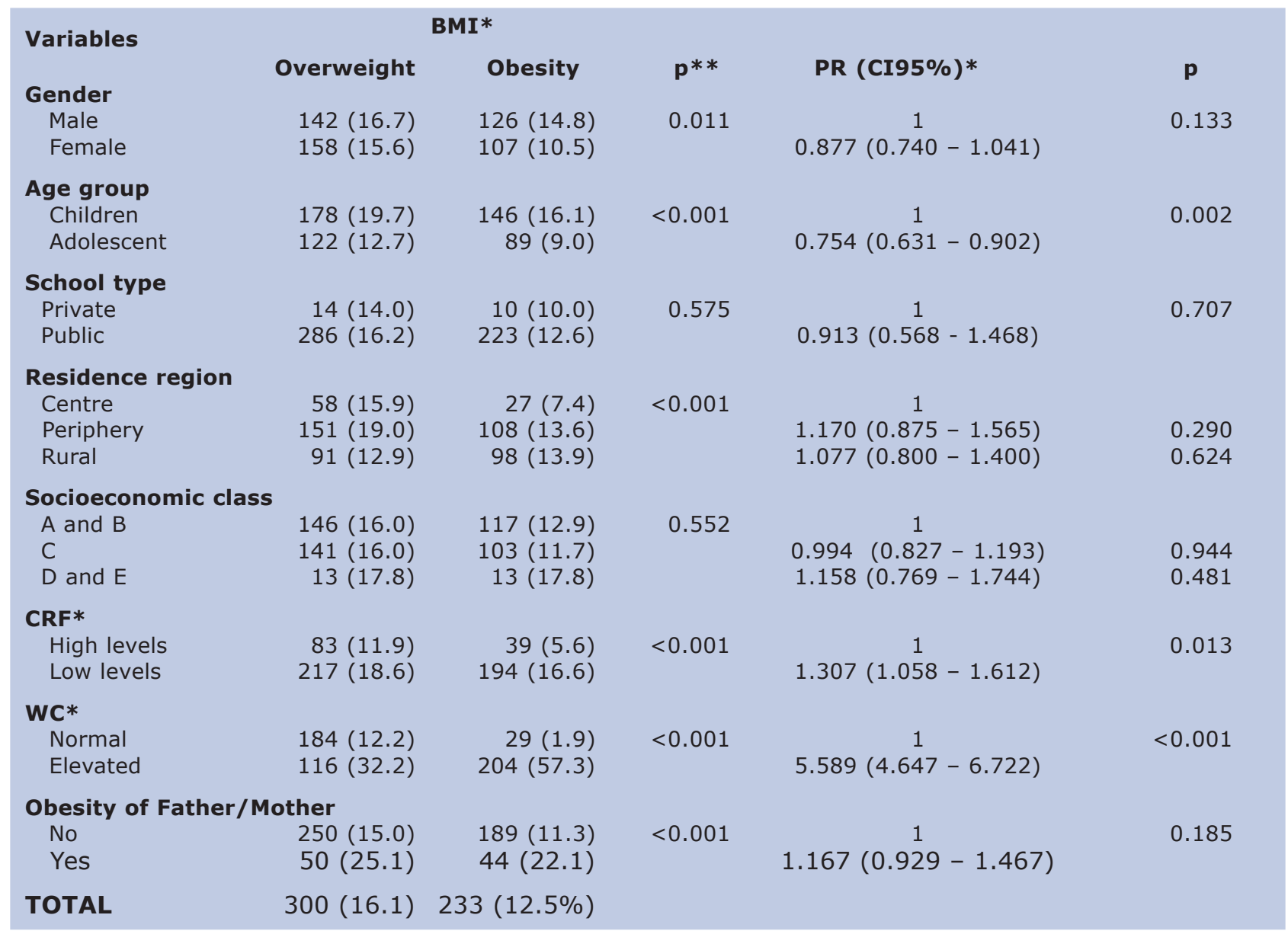

* $\quad \mathrm{BMI}=$ body mass index; PR = prevalence ratio; CI95\%: 95\% confidence interval; CRF = cardiorespiratory fitness; WC = waist circumference.

$* *$ chi square test: $\mathrm{p}<0,05$.

also more prevalent among the students with high BMIs and more prevalent among the obese children compared with overweight children and among the overweight children compared to the normal weight schoolchildren. High blood pressure differences were not found according to the type of school, region of residence, economic class or cardiorespiratory fitness. The adolescents exhibited a prevalence of high BP that was 1,173 ( $p<0.001$ ) times greater than that of the children (Table 4). 
Table 4: Prevalence of high blood pressure according to the studied variables and prevalence ratios for high blood pressure

\begin{tabular}{|c|c|c|c|c|c|}
\hline \multirow{2}{*}{ Variables } & \multicolumn{2}{|c|}{ BP* } & \multirow[b]{2}{*}{ p** } & \multirow[b]{2}{*}{ PR (CI95\%)* } & \multirow[b]{2}{*}{$\mathbf{p}$} \\
\hline & Borderline & Hypertensive & & & \\
\hline Male & $81(9.5)$ & $79(9.3)$ & \multirow{2}{*}{0.001} & 1 & \multirow{2}{*}{0.388} \\
\hline Female & $55(5.4)$ & $81(8.0)$ & & $0.963(0.884-1.049)$ & \\
\hline \multicolumn{6}{|l|}{ Age group } \\
\hline Children & $19(2.1)$ & $50(5.5)$ & \multirow[t]{2}{*}{$<0.001$} & 1 & \multirow[t]{2}{*}{$<0.001$} \\
\hline Adolescent & $117(12.2)$ & $110(11.4)$ & & $1.173(1.075-1.281)$ & \\
\hline \multicolumn{6}{|l|}{ School type } \\
\hline Private & $5(5.0)$ & $6(6.0)$ & \multirow[t]{2}{*}{0.393} & 1 & \multirow[t]{2}{*}{0.920} \\
\hline Public & $131(7.4)$ & $154(8.7)$ & & $1.011(0.812-1.259)$ & \\
\hline \multicolumn{6}{|c|}{ Residence region } \\
\hline Centre & $32(8.8)$ & $22(6.0)$ & \multirow[t]{3}{*}{0.070} & 1 & \\
\hline Periphery & $46(5.8)$ & $78(9.8)$ & & $1.019(0.889-1.167)$ & 0.788 \\
\hline Rural & $58(8.2)$ & $60(8.5)$ & & $1.008(0.880-1.155)$ & 0.904 \\
\hline \multicolumn{6}{|c|}{ Socioeconomic class } \\
\hline$A$ and $B$ & $77(8.5)$ & $70(7.7)$ & \multirow[t]{3}{*}{0.225} & 1 & \\
\hline C & $56(6.3)$ & $82(9.3)$ & & $1.002(0.915-1.098)$ & 0.961 \\
\hline $\mathrm{D}$ and $\mathrm{E}$ & $3(4.1)$ & $8(11.0)$ & & $0.989(0.790-1.229)$ & 0.926 \\
\hline \multicolumn{6}{|l|}{ BP* } \\
\hline LW*/Normal & $88(6.6)$ & $72(5.4)$ & \multirow[t]{3}{*}{$<0.001$} & 1 & \\
\hline Borderline & $26(8.7)$ & $34(11.3)$ & & $1.079(0.948-1.229)$ & 0.251 \\
\hline Hipertensive & $22(9.4)$ & $54(23.2)$ & & $1.165(0.970-1.400)$ & 0.102 \\
\hline \multicolumn{6}{|l|}{ WC* } \\
\hline Normal & $100(6.6)$ & $94(6.2)$ & \multirow[t]{2}{*}{$<0.001$} & 1 & \multirow[t]{2}{*}{0.561} \\
\hline Elevated & $36(10.1)$ & $66(18.5)$ & & $1.047(0.896-1.225)$ & \\
\hline \multicolumn{6}{|l|}{ CRF* } \\
\hline High levels & $52(7.4)$ & $47(6.7)$ & \multirow[t]{2}{*}{0.088} & 1 & \multirow[t]{2}{*}{0.826} \\
\hline Low levels & $84(7.2)$ & $113(9.7)$ & & $0.990(0.904-1.084)$ & \\
\hline \multicolumn{6}{|c|}{$\begin{array}{l}\text { Hypertension } \\
\text { of Father/Mother }\end{array}$} \\
\hline No & $83(6.1)$ & $101(7.5)$ & \multirow[t]{2}{*}{$<0.001$} & 1 & \multirow[t]{2}{*}{0.286} \\
\hline Yes & $53(10.3)$ & $59(11.5)$ & & $1.052(0.958-1.115)$ & \\
\hline TOTAL & $136(7.3)$ & $160(8.6)$ & & & \\
\hline
\end{tabular}

${ }^{*} \mathrm{BP}=$ blood pressure; $\mathrm{PR}=$ prevalence ratio; $\mathrm{CI} 95 \%$ : $95 \%$ confidence interval; $\mathrm{BMI}=$ body mass index; $\mathrm{LW}=\mathrm{low}$ weight; $\mathrm{WC}=$ waist circumference; $C R F=$ cardiorespiratory fitness. ${ }^{* *}$ chi square test: $p<0,005$.

\section{DISCUSSION}

This study found a prevalence of excess weight of $28.6 \%$ ( $16.1 \%$ overweight and $12.5 \%$ obese), and excess weight was more prevalent among the male students. A previous study in this city revealed that the prevalence of overweight are increasing among boys and decreasing among girls ${ }^{14}$. Several studies corroborate to our results and have reported tendencies for overweight rates that are higher among male children and adolescents ${ }^{1,15-17}$. In a study conducted in Minas Gerais, the male gender exhibited a 1.86-fold increase in the risk of excess weight ${ }^{18}$. A previous study by Ribeiro et al. ${ }^{19}$ revealed that girls are at a reduced risk of overweight $(P R=0.81)$.

The age range was significantly related to the prevalence of excess weight in this study; specifically, the children more prone to this risk factor than the adolescents. Similarly, a study conducted in Spain found that the prevalence of overweight was significantly higher among students of aged 8-13 years compared with adolescents aged 14 to 17 years ${ }^{17}$. Another found that adolescents in China and Russia ${ }^{20}$ were 0.4 and 0.3 times less likely, respectively, to fall into the overweight or obese range than children. Similarly, in our study, adolescents were at a lower risk for overweight $(P R=0.754)$. A previous study in Canada found that the prevalence of overweight and obesity was similar across age groups ${ }^{21}$. In contrast to our findings, a study by Ribeiro et al. ${ }^{19}$ found that children are at a reduced risk of excess weight $(P R=0.54)$.

Regarding the economic variables, no significant differences were found according to the type of school or economic class of the school children, although the results revealed that the prevalence of overweight was higher among the lower classes and among the public school students. Similar results were found in a study conducted in the US in which children from lower socioeconomic levels exhibited the highest prevalence of overweight. However, in this same study, the opposite inverse relationship was observed in China; 
i.e., the children and adolescents of high socioeconomic status exhibited greater prevalence of overweight and obesity ${ }^{20}$.

The data from our study seem to differ from those of the majority of the existing studies in the literature regarding these issues. However, Alves et al. ${ }^{3}$ provided a warning about the inconsistencies of the relationship between excess weight and economic level, which do not follow a set pattern. A study in Singapore revealed that the risk of overweight was significantly higher among the highest economic classes (A-B) and among private schools ${ }^{5}$. In a study conducted in Espirito Santo, students from higher income homes were found to be 1.78 -fold more likely to be overweight compared with low-income students 22 .

In a previous study conducted in Pernambuco, no significant association between overweight and family income was observed ${ }^{3}$. However, research conducted in northeastern Brazil corroborates our study in that the prevalence of excess weight was found to be higher among the lower classes; however, this difference was not significant. Nevertheless, in this same study, differences were identified by between public and private schools; the prevalence of excess weight was greater in the private schools 4 .

However, with respect to socioeconomic variables, residence in the periphery found to be associated with significantly higher prevalence of overweight and obesity compared with the central and rural areas of the Santa Cruz do Sul municipality. In a study conducted in the Brazilian northeast ${ }^{4}$, school in areas of better economic conditions exhibited a higher prevalence of excess weight than those in the north and west; this result contrasts our finding that prevalence of excess weight was greater among the students from underprivileged economic regions.

The prevalence of overweight and obesity was higher among the students whose fathers and/or mothers were obese among those with low levels of cardiorespiratory fitness and high WCs. The students with high waist circumferences and low levels of cardiorespiratory fitness presented excess weight prevalence that was elevated by $5.589-(p<0.001)$ and 1.307 -fold $(p=0.013)$, respectively. A study conducted in Santa Cruz do Sul and another conducted in the Espírito Santo state revealed that students with low levels of cardiorespiratory fitness exhibit higher frequencies of overweight and obesity than those with satisfactory cardiorespiratory fitnesses 23,24. However, the study conducted in Espírito Santo revealed that male and female students with low levels of cardiorespiratory fitness exhibited 9.98and 4.81 -fold increases in the risk of excess weight, respectively.

In a study conducted in Argentina, excess weight was also found to be associated with obesity in the parents ${ }^{25}$. Additionally, a study conducted in São Paulo found an association between the prevalence of excess weight among the parents and overweight among the children; these prevalences were $9.3 \%$ among the students whose parents did not have excess weight, $17.6 \%$ among those who had one parent with this condition and $26.1 \%$ among those with two parents carrying excess weight $^{26}$. In a study conducted in the municipality of Capão da Canoa (RS), the prevalence of overweight and obesity was significantly higher among the students whose fathers, mothers or both were obese. The risk of excess weight among schoolchildren with at least one parent who is overweight is increased by approximately $50 \%{ }^{27}$. In a study conducted in Espirito Santo, schoolchildren with mothers with BMIs greater than $25.0 \mathrm{~kg} / \mathrm{m}^{2}$ were found to be at a 2.04 -fold increased risk of excess weight ${ }^{22}$.

Regarding blood pressure, the presence of high blood pressure was $15.9 \%$ among the students of Santa Cruz do Sul including $7.3 \%$ and $8.6 \%$ of schoolchildren who were classified as borderline and hypertensive, respectively. Another study in the same municipality revealed that the prevalence of high pressure is increasing among students ${ }^{14}$.

Regarding overweight, the prevalence of HBP was significantly higher among the males. Similar results have been reported in studies conducted in n Minas Gerais ${ }^{1}$, Tunisia ${ }^{28}$, Paraiba ${ }^{15}$ and South Africa ${ }^{6}$. Previous research in Alagoas $^{5}$ and Piauí ${ }^{7}$ revealed no significant differences between genders. In contrast to the excess weight results observed in this study, the prevalence of HBP was higher among the adolescents than the children. These adolescents exhibited a prevalence of HBP that was 1,173 -fold $(p<0.001)$ greater than that of the children. A study conducted in Canada reported that the prevalence of high systolic blood pressure increased with age ${ }^{21}$.

Regarding the variables related to economic class, neither the school type nor the housing region exhibited a relationship with the prevalence of hypertension in schoolchildren. In contrast, in Caxias do Sul (RS), significant differences related the type of school have been observed; the private schools were found to have a prevalence of high blood pressure that was nearly twice that of the public schools. Additionally, the children with higher socioeconomic statuses were 2.6 times more likely to have elevated blood pressure ${ }^{29}$. A study conducted in Minas Gerais and another conducted in three large Brazilian cities revealed increases in the risk of high systolic blood pressure of 3.95- and 2.48-fold, respectively, among the students of public schools ${ }^{18,19}$. A study conducted in Alagoas ${ }^{5}$ reported no association between hypertension and the type of school; however, an association between hypertension and membership in the highest economic classes was observed. In a study conducted in Paraiba, adolescents in the intermediate and lower income classes were 1.73and 3.10-fold more likely, respectively, to have higher blood pressure than students in the highest economic classes ${ }^{15}$.

The prevalence of high blood pressure was also significantly higher among the students with high BMIs and WCs and among those whose fathers and/or mothers had hypertension. However, regarding cardiorespiratory fitness, there were no differences in the prevalence of HBP between the students with high and low levels of 
cardiorespiratory fitness. Similarly, in a study conducted in the Espírito Santo state, no relationship between blood pressure differences and poor physical fitness were found ${ }^{22}$.

A study conducted in the municipality of Santa Cruz do Sul revealed that schoolchildren with low levels of cardiorespiratory fitness were more likely to have high blood pressure than those with good levels of cardiorespiratory fitness, albeit, this difference was no significant ${ }^{23}$. A previous study conducted in Caxias do Sul (RS) found higher levels of cardiorespiratory fitness to be a protective factor against high blood pressure $(O R=0.794)^{29}$. Regarding the presence of hypertension in the parents, a study conducted in Argentina corroborates our findings; i.e., the adolescents with hypertensive mothers and fathers were 1.38-fold and 1.32 -fold more likely to have hypertension, respectively ${ }^{25}$.

The relationship between high blood pressure and overweight is clearly defined in the existing literature; several studies have found that high BMIs $^{1,2,16,28}$ and high WCs ${ }^{2,29}$ are associated with high blood pressure. Overall, in the reviewed studies, the risk of high blood pressure among schoolchildren with excess weight are elevated by between 1.50and 4.9-fold $1,16,19,27-29$.

Furthermore, among students with WCs, the risk of high blood pressure is elevated by 3.84-fold ${ }^{2}$. In a study conducted in Paraiba with overweight and

\section{REFERENCES}

1. Nobre LN, Sammour SNF, Costa Sobrinho PS. Índice de massa corporal e circunferência de cintura como preditores de pressão arterial alterada em adolescentes. Rev Med Minas Gerais. 2011 ; 21(4): 404-12.

2. Domingos $\mathrm{E}$, Domingues $\mathrm{V}$, Pires Júnior $\mathrm{R}$, Caldeira AS, Christofaro DGD, Casonatto J. Associação entre estado nutricional antropométrico, circunferência de cintura e pressão arterial em adolescentes. Rev Bras Cardiol. 2013; 26(2): 94-9.

3. Alves JGB, Siqueira PP, Figueiroa JN. Overweight and physical inactivity in children living in favelas in the metropolitan region of Recife, Brazil. J Pediatr (Rio J). 2009; 85(1): 67-71. DOI: http://dx.doi.org/10.2223/JPED.1862

4. Brasil LMP, Fisberg M, Maranhão HS. Excesso de peso de escolares em região do Nordeste Brasileiro: contraste entre as redes de ensino pública e privada. Rev Bras Saúde Matern Infant. 2007; 7(4): 405-12. DOI: http:// dx.doi.org/10.1590/S1519-38292007000 400008

5. Silva MAM, Rivera IR, Mendonça MR, Ferraz T, Pinheiro AJT, Alves SWS, et al. Prevalência de fatores de risco cardiovascular em crianças e adolescentes da rede de ensino da cidade de Maceió. Arq Bras Cardiol. 2005; 84(5): 38792. doi: http://dx.doi.org/10.1590/S0066$782 \times 2005000500007$

6. Moselakgomo VK, Toriola AL, Shaw BS, Goon DT, Akinyemi O. Índice de massa corpórea, so- obese children and adolescents, $70.5 \%$ of students were found to have high blood pressure; among these students, only $6 \%$ had high systolic blood pressure, $33 \%$ had high diastolic pressure, and $31.5 \%$ had both. However, higher systolic blood pressure values were observed in the children with severe obesity and increased waist circumferences ${ }^{30}$.

The prevalence of overweight and high blood pressure was increased among the schoolchildren from the investigated city, which demonstrates the need for the control and prevention of these conditions.

\section{CONCLUSION}

We concluded the factors that were associated with overweight and high blood pressure among the schoolchildren from the city of Santa Cruz do Sul were cardiorespiratory fitness, increased waist circumference and family history. Additionally, the male children and adolescents were more likely to have excess weight and altered blood pressure. Excess weight was more prevalent among the children, while high blood pressure was more prevalent among the adolescents. Finally, socioeconomic variables, such as the type of school, place of residence and economic class, did not influence the studied factors.

brepeso e pressão arterial em escolares na província de Limpopo, África do Sul. Rev Paul Pediatr 2012; 30(4): 562-9. DOI: http:// dx.doi.org/10.1590/S0103-05822012000 400015

7. Costa JV, Silva ARV, Moura IH, Carvalho RBN, Bernardes LE, Almeida PC. Análise de fatores de risco para hipertensão arterial em adolescentes escolares. Rev Latino-Am Enfermagem. 2012; 20(2): 289-95. DOI: http://dx.doi.org/ 10.1590/S0104-11692012000200011

8. Brasil. Câmara dos Deputados. Estatuto da Criança e do adolescente: Lei no 8.069, de 13 de julho de 1990, e legislação correlata. 9 ed. Brasília: Câmara edições; 2012.

9. Associação Brasileira de Empresas de Pesquisa $(A B E P)$. Critério de Classificação Econômica Brasil 2012. [cited 2015 Aug 07] Available from: http://www.abep.org/criterio-brasil

10. Centers for Disease Control and Prevention (CDC). Growth Charts: 2000 CDC Growth Charts for the United States: Methods and Development. [cited 2015 Aug 07] Available from: http://www.cdc.gov/growthcharts

11. Taylor RW, Jones IE, Willians SM, Goulding A. Evaluation of waist circumference, waist-to-hip ratio, and the conicity index as screening tools for high trunk fat mass, as measured by dualenergy X-ray absorptiometry, in children aged 3-19 y. Am J Clin Nutr. 2000; 72(2): 490-5.

12. Sociedade Brasileira de Cardiologia. Sociedade Brasileira de Hipertensão. Sociedade Brasileira de Nefrologia. VI Diretrizes Brasileiras de Hipertensão. Arq Bras Cardiol. 2010; 95(Suppl 
1): 1-3. DOI: http://dx.doi.org/10.1590/ S0066-782X2010001700001

13. Projeto Esporte Brasil (PROESP). Manual de aplicação de medidas e testes, Normas e Critérios de Avaliação. Porto Alegre: Universidade Federal do Rio Grande do Sul. 2009. [cited 2015 Aug 07] Available from: http:// passthrough.fw-notify. net/download/180711/ http://sis.posugf.com.br/Area Professor/Materiais/Arquivos_1/7972.pdf

14. Reuter EM, Reuter CP, Burgos LT, Reckziegel MB, Nedel FB, Albuquerque IM, et al. Obesidade e hipertensão arterial em escolares de Santa Cruz do Sul - RS, Brasil. Rev Assoc Med Bras. 2012; 58(6):666-72. DOI: http://dx.doi.org/ 10.1590/S0104-42302012000600010

15. Farias Júnios JC, Mendes JKF, Barbosa DBM, Lopes AS. Fatores de risco cardiovascular em adolescentes: prevalência e associação com fatores sócio-demográficos. Rev Bras Epidemiol. 2011; 14(1): 50-62. DOI: http:// dx.doi.org/10.1590/S1415-790X2011000 100005

16. Lu X, Shi P, Luo CY, Zhou YF, Yu HT, Guo CY, et al. Prevalence of hypertension in overweight and obese children from a large school-based population in Shanghai, China. BMC Public Health. 2013; 13: 24. DOI: http://dx.doi.org/ 10.1186/1471-2458-13-24

17. Sánchez-Cruz JJ, Jiménez-Moleón JJ, Fernández-Quesada F, Sánchez MJ. Prevalencia de obesidad infantil y juvenil en España en 2012. Rev Esp Cardiol. 2013; 66 (5): 371-6. DOI: http://dx.doi.org/10.1016/j.recesp. 2012.10.016

18. Ribeiro RQC, Lotufo PA, Lamounier JA, Oliveira RG, Soares JF, Botter DA. Fatores adicionais de risco cardiovascular associados ao excesso de peso em crianças e adolescentes. O estudo do coração de Belo Horizonte. Arq Bras Cardiol. 2006, 86(6): 408-18. DOI: http://dx.doi.org/ 10.1590/S0066-782X2006000600002

19. Ribeiro RC, Coutinho M, Bramorski MA, Giuliano IC, Pavan J. Association of the Waist-to-Height Ratio with Cardiovascular Risk Factors in Children and Adolescents: The Three Cities Heart Study. Int J Prev Med. 2010; 1(1): 39-49.

20. Wang Y. Cross-national comparison of childhood obesity: the epidemic and the relationship between obesity and socioeconomic status. Int J Epidemiol. 2001; 30(5):1129-36. DOI: http:/ /dx.doi.org/10.1093/ije/30.5.1129

21. Paradis G, Lambert M, O'Loughlin J, Lavallée C, Aubin J, Delvin E, et al. Blood pressure and adiposity in children and adolescents. Circulation. 2004; 110(13): 1832-8. DOI: http://dx.doi.org/10.1161/01.CIR.0000 143100.31752.B7

22. Salvador CCZ, Kitoko PM, Gambardella AMD. Estado nutricional de crianças e adolescentes: fatores associados ao excesso de peso e acúmulo de gordura. J Hum Growth Dev 2014; 24(3): 313-319. DOI: http://dx.doi.org/ 10.7322/jhdg.88969

23. Rodrigues AN, Perez AJ, Carletti L, Bissoli NS, Abreu GR. The association between cardiorespiratory fitness and cardiovascular risk in adolescents. J Pediatr (Rio J). 2007; 83(5): 429-35. DOI: http://dx.doi.org/10.1590/ S0021-75572007000600006

24. Burgos MS, Reuter CP, Burgos LT, Pohl HH, Pauli LTS, Horta JA, et al. Uma análise entre índices pressóricos, obesidade e capacidade cardiorrespiratória em escolares. Arq Bras Cardiol. 2010; 94(6): 739-44. DOI: http://dx.doi.org/ 10.1590/S0066-782X2010005000046

25. Paterno CA. Coronary risk factors in adolescence. The Fricela Study. Rev Esp Cardiol. 2003; 56(5): 452-8.

26. Ramos AMPP, Barros Filho AA. Prevalência da obesidade em adolescentes de Bragança Paulista e sua relação com a obesidade dos pais. Arq Bras Endocrinol Metab. 2003; 47(6): 663-8. DOI: http://dx.doi.org/10.1590/S000427302003000600007

27. Moser DC, Giuliano ICB, Titski ACK, Gaya AR, Coelho-e-Silva MJ, Leite N. Anthropometric measures and blood pressure in school children. J Pediatr 2013; 89(3): 243-9. DOI: http:// dx.doi.org/10.1016/j.jped.2012.11.006

28. Aounallah-Skhiri $H$, Ati J, Traissac $P$, Romdhane $\mathrm{HB}$, Eymard-Duvernay S, Delpeuch $\mathrm{F}$, et al. Blood pressure and associated factors in a North African adolescent population. A national crosssectional study in Tunisia. BMC Public Health. 2012; 12: 98. DOI: http://dx.doi.org/ 110.1186/1471-2458-12-98

29. Costanzi CB, Halpern R, Rech RR, Bergmann MLA, Alli LR, Mattos AP. Associated factors in high blood pressure among schoolchildren in a middle size city, southern Brazil. J Pediatr (Rio J). 2009; 85(4):335-40. DOI: http://dx.doi. org/10.2223/JPED. 1913

30. Noronha JAF, Ramos ALC, Ramos AT, Cardoso MAA, Carvalho DF, Medeiros CCM. Pressão arterial elevada em crianças e adolescentes com excesso de peso. Rev Bras Crescimento Desenvolv Hum. 2012; 22(2): 196-201. 


\section{Resumo}

Introdução: Estudos atuais vêm apontando para o aumento das taxas de sobrepeso e obesidade e de fatores de risco cardiovasculares, como a hipertensão, em idades cada vez menores. No entanto, as causas e os fatores associados a este aumento ainda são de difícil de determinação. Objetivo: Identificar os fatores associados e a prevalência de excesso de peso e níveis pressóricos entre os escolares. Método: A amostra envolveu 1867 escolares. Os dados foram obtidos por meio de avaliações antropométricas, medidas da pressão arterial, avaliação cardiorrespiratória e aplicação de questionários. Utilizou-se estatística descritiva, qui-quadrado e regressão de Poisson $\left(p d^{\prime \prime} 0,05\right)$. Resultados: $28,6 \%$ e $15,9 \%$ dos escolares apresentaram excesso de peso e pressão elevada, respectivamente. O sexo masculino mostrou-se mais suscetível a ambos os fatores de risco estudados. Adolescentes apresentaram prevalência 1,173 vezes maior de pressão elevada que as crianças. Já, para o excesso de peso, a adolescência apresentou-se como fator de proteção $(R P=0,754)$. Escolares com circunferência da cintura elevada e aptidão cardiorrespiratória insatisfatória apresentaram prevalência de 5,5 e 1,3 vezes maior de excesso de peso, respectivamente. Conclusão: A prevalência de excesso de peso e pressão elevada na população escolar se mostrou alta no município investigado. Aptidão cardiorrespiratória, circunferência da cintura elevada e o histórico familiar mostraram influenciar no excesso de peso e nos níveis pressóricos elevados.

Palavras-chave: sobrepeso, obesidade, pressão arterial, fatores de risco, criança, adolescente. 